\title{
DISCUSSIONS
}

\section{METHODOLOGICAL APPROACHES TO CLIMATE CHANGE VULNERABILITY ASSESSMENT OF PROTECTED AREAS}

\author{
Oksana N. Lipka \\ World Wildlife Fund Russia, Russia \\ e-mail:olipka@wwf.ru
}

Received: 08.05.2017

\begin{abstract}
Climate change impacts in Russia's territory make species and ecosystems conservation in Protected Areas a more difficult challenge. Additional adaptation measures are required. Before they are developed, it is important to assess the vulnerability of a territory: what exactly, and to which extent, is exposed to adverse climate impacts? The accomplished research will help develop an action plan consistent with the current unstable climate and extreme weather events, as well as with projections by the leading research institutions of Roshydromet and the Russian Academy of Science. Today, methodologies have been developed and successfully tested for some natural zones. The conservation science is now facing a new challenge: how to combine collected information with climate projections and identify development perspectives for concrete territories.
\end{abstract}

Key words: climate change, climate change vulnerability, Protected Areas

\section{Articulation of problem and sources of information}

Over the recent 30 or 40 years, a climate change, which is basically induced by the increasing concentration of atmospheric $\mathrm{CO}_{2}$, has explicitly manifested in the larger part of our country through changes in the average air temperatures and duration of seasons and through growing frequency and intensity of natural hazards (Assessment Report, 2008; Second Assessment Report, 2014; Report on climate features, 2017).

Species and ecosystems are responding to this changing environment. The following reactions have been noted: shifts in species' habitats, often along the altitudinal gradient; changes in life cycle stages, or phenology, of species; broken co-evolution ties, such as between plants and pollinators; impact on demographic indicators, such as survival and fertility; reducing populations (particularly of boreal and mountain species); extinction or displacement of isolated, restricted range of endemic species and populations; loss of habitats with the rising sea level and increasing frequency of wildfires and bark beetle manifestations; changing weather conditions, glacier retreats, and direct increase in the air temperature in habitats (for example, in mountain rivers); active propagation of diseases, parasites and zoonoses (including Lyme disease and plagues) that are natural in the wild world; increasing populations of invasive species that are direct competitors to native protected species; propagation of invasive species, including plants, animals, and micro-organisms (Mawdslew et al., 2009; Post et al., 2009).

Nature protection in a changing environment is a more difficult challenge than in a stable climate. Some 30 years ago, the general belief was that species protection was about saving species from direct adverse anthropogenic impacts; however, with a new factor added, it is important to take another look at the problem and decide if the measures being taken are sufficient. What management decisions should be taken to guarantee species protection today and after 20 or 30 years?

Decision-making should be informationbased: what is happening in Protected Areas (PA)? How has the environment changed? How does climate change affect protected species and ecosystems (favourably or adversely)? In other words, vulnerability (resilience) assessment should be the first step of adaptation measure development.

Therefore, the conservation science is currently facing a new challenge which largely determines successful conservation of species and ecosystems in PAs.

The purpose of this research is to systematise domestic experience in estimating a territory's vulnerability to climate change for further application in PAs.

The goals are:

- to analyse the available methodologies and data sources related to climate change in individual territories;

- to assess their practicability for PA climate change's vulnerability estimations. 


\section{Terminology}

There are many definitions of vulnerability and resilience in biology/ecology/geography. Since this research deals with climate change, it uses definitions as adopted by the World Meteorological Organization (WMO), Intergovernmental Panel on Climate Change (IPCC), and Roshydromet:

Vulnerability - is a system's exposure to adverse impacts of climate change and/or inability to offset these impacts. It is rarely determined by only one factor; rather, it is a product of a variety of natural, anthropogenic, and social processes (IPCC, 2013, 2014). Vulnerability assessment should take account of additional, other than climate, factors.

Resilience - is the ability of social, economic, or natural ecosystems to cope with disaster impacts or climate change trends: to offset the external impacts, i.e. keep functioning effectively (IPCC, 2014).

Adaptation - is the adjustment in natural or human systems in response to actual or expected climate stimuli or their effects, which moderates harm or exploits beneficial opportunities (IPCC, 2014).

The 1961-1990 climate is normally taken for baseline, because this is the period when climate change effects manifested on a small-scale, if at all.

Abundant climatology terms make it difficult for professionals from other areas to understand and use the information. National and international climate change assessment reports always include glossaries of terms. Smaller bilingual thematic glossaries can also be used (Kokorin et al., 2015). In order to get a basic understanding and start work it would be sufficient to familiarise with simple, yet scientifically correct, educational courses for a diverse audience, for example, developed by WWF US «What is climate change?», «Key concepts in climate change adaptation», «Understanding vulnerability», "Wildlife and climate change» (WWF Adapt, 2017). Most of them have been translated into Russian and can be used, inter alia, for training courses.

More information about natural climate cycles of different duration versus today's climate change can be found in Assessment Reports (2008, 2014) or in the literature specially adapted for non-climatologists (Kokorin et al., 2013a,b).

Data from Roshydromet's main weather stations are available free of charge to those registered at the website of Russian research institute for hydrometeorological information - global data centre (http://meteo.ru/data).

Plenty of useful information, in addition to weather forecasts, can be found on Roshydromet's website (http://www.meteorf.ru/product/info/). Some of this information is only for individual regions so far: Meteo-Alarm is for mapping hazards in the territories of Central and North-West Federal Districts, to provide urgent information on hazardous situations, forecasts of dangerous and unfavourable weather events in Russia's territory, maps of wildfire hazards in forests throughout Russia and Moscow Region, overview of agrometeorological conditions and development perspectives, mapping meteorological extrema over the last 24 hours, operational satellite imagery by Federal Institution «NITs "Planeta"», wildfire monitoring, thunderstorm records, etc.

\section{Methods and data \\ to assess climate change vulnerability}

Various methodologies to assess climate change vulnerability of territories and facilities have been being increasingly published over the recent years. They normally include some standard stages that can be found in several sources, both Russian and foreign. An example of such a methodology to assess the vulnerability of the Altay-Sayan ecoregion (Kokorin et al., 2011) is presented below:

1) description of territory and forecast of potential change induced by current plans for the region's social and economic development (ecosystems, species, traditional natural resource management in PAs, tourism development perspectives, potential change in zoning/borders, etc.);

2) analysis of observed and potential impacts of climate change by types of hazards;

3) vulnerability assessment by types of hazards and total potential damage scenarios;

4) identification and cost estimates of potential adaptation measures;

5) identification of information gaps and directions for further research.

Integration of economic parameters and current action plans into climate change vulnerability assessments allows for a more comprehensive picture. Since direct cost estimates of natural ecosystems and, therefore, of the damage caused, cannot be obtained, economic estimates may substantially differ depending on the indirect methods used. Therefore, it would be useful to supplement economic estimates with other indicators, such as the number of individuals of rare and endangered species, area of high fire/flood/mudflow/avalanche risk, etc. (Kokorin et al., 2011).

Where large grants are available abroad for scientific research, special modelling of climate 
change is used to assess vulnerability. It is normally practiced for a territory much larger than a PA, (for example, for the Mediterranean) and produces several climate change scenarios to the end of the XXI century. Climate maps are developed based on the projections obtained. An assessment was made, as to which part of the current Mediterranean-climate zones will be covered by Mediterranean landscapes in the future. Whereas in Chili Mediterranean-climate regions are expected to show 129-153\% increase, in Australia they will shrink to $77-49 \%$ depending on the scenario. Today, only $4 \%$ of Mediterranean-climate zones on earth are protected (versus $12 \%$ global average for all types of biomes). Depending on the emission scenarios, only $50-60 \%$ of the current PAs will remain Mediterranean-climate zones. At the same time, anthropogenic pressure will aggravate leading to the degradation of landscapes. The authors' recommendation is to get started planning and establishing a new PA and ecological corridors to ensure species migration and protection within the new borders of Mediterranean-climate landscapes (Klausmeyer \& Shaw, 2009).

Modelling helps identify the ecosystem shift velocity and find new refugia for species. In the context of climate change, a PA with a larger territory and greater landscape diversity is more effective in terms of species and ecosystems protection. For the purpose of risk mitigation it is recommended to increase the territory of existing PAs, particularly in the most vulnerable regions (Loarie et al., 2009).

The downside of the methodologies above is their low spatial resolution. Vulnerability assessments determine how climate zones will shift, and so how landscapes and species distribution will change. They do not consider a concrete PA with its specific set of species and ecosystems, but rather formulate findings based on general regional trends.

However, with strong and clear climate change trends, even a regional-level projection provides good enough grounds for national-level decisionmaking. For example, the III-VI National Communication of Kazakhstan Republic to the United Nations Convention on Climate Change (UNFCCC) (2013) states, that the current climate change velocity accelerates, and so natural adaptation is practically unfeasible (meaning exacerbating aridization of climate in the country). The basic challenge, in terms of ecosystems conservation, is to assist species and ecosystems in adjusting to the new conditions in their habitats. Ecological corridors, as one type of PA, are created exactly for this reason; the same is true for changes in land use and resource management systems and monitoring of etalon types of ecosystems in PA. There are plans to sustain natural populations of rare species through artificial reproduction, to restore damaged natural ecosystems, to prevent invasion of alien species that are aggressive to the native ones, etc. Goals are formulated as the development of short- and long-term projections for vulnerable ecosystems and indicative plant and animal species, risk assessment for endangered populations, species, and communities (III-VI National Communication, 2013).

Another approach implies the estimation of climate change vulnerability and dynamics of individual species. Habitats are mapped with various temporal and spatial resolutions to further estimate if the future habitat of a rare species is located within PAs of particular types, to suggest ecological corridors and identify territories to ensure the survival of a particular species (Hannah et al., 2005; Hannah, 2008). Likewise assessments are made for marine PAs (McLeod et al., 2009). In an existing PA, it is recommended to identify, and primarily seek to protect, areas that provide important resources for animals, such as water, food, and shelter, and will keep performing their functions in the decades to come (Olson et al., 2009).

So far, research efforts that look to assess climate change implications for a concrete PA and species are sporadic. Typically, the goal is to estimate a territory's overall vulnerability with climate factors viewed as indirect anthropogenic impacts (Ervin, 2003).

In Africa, a research was accomplished based on important bird areas (Hole et al., 2011). Not only did it project the evolution of natural environments and species distribution, but also provide recommendations for adaptation measures by PAs (Fig. 1).

A simplified methodology to assess longterm resilience to changing natural environments was developed specifically for Russia's Protected Areas (Stishov, 2012). It is helpful for primary assessments of climate change impacts on PAs, particularly where detailed climate information is not available.

According to Stishov (2012), there are two aspects to $\boldsymbol{P A}$ resilience:

1) conservation sustainability, i.e. a territory's potential to sustain its natural complexes and elements thereof in their current form (is determined by a territory's geographical position, area, and landscape diversity, as well as by climate change resilience of the lithogenic base of landscapes); 


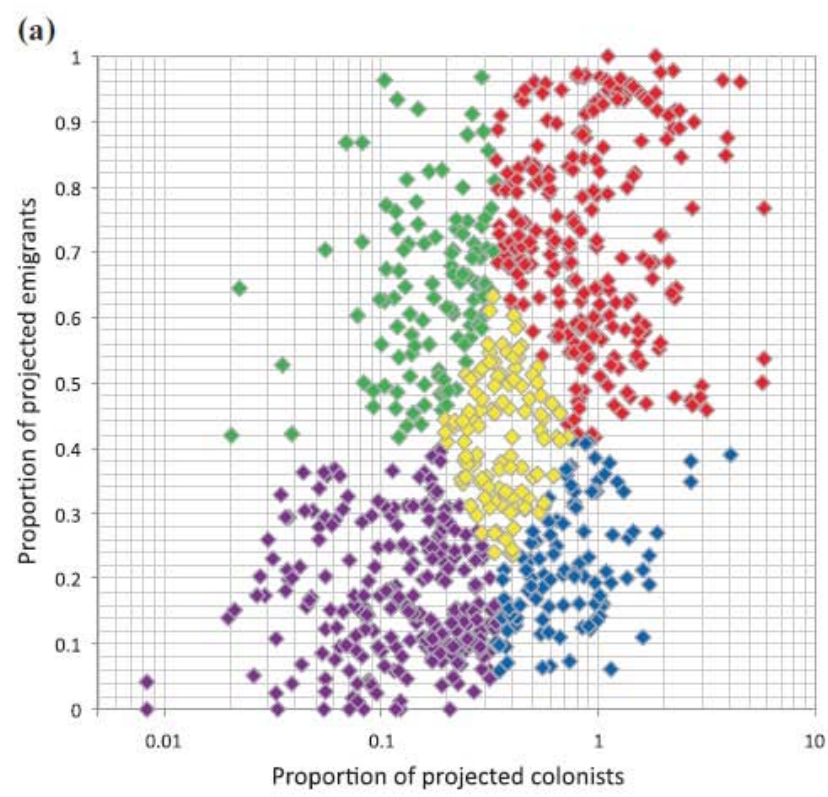

(b)

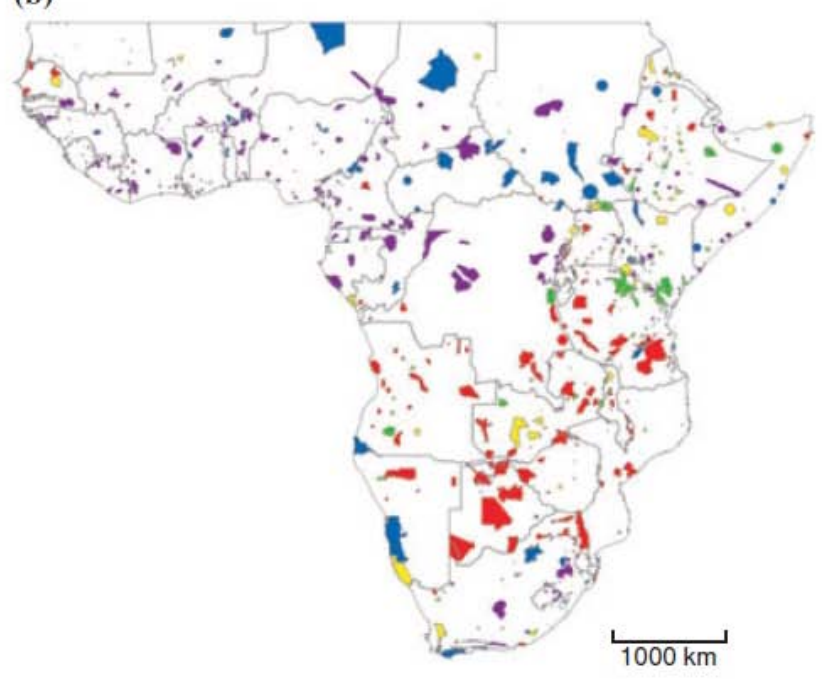

Fig. 1. (a) Proportion of priority bird species projected to emigrate relative to proportion of priority species projected to colonize (log scale) by 2085 each of the 803 mainland sub-Saharan Africa Important Bird Areas (IBAs). Climate-change adaptation strategy (CCAS) categories into which IBAs are classified are purple, high persistence; green, increasing specialization; red, high turnover; blue, increasing value; yellow, increasing diversification. (b) Spatial distribution of IBAs in the five CCAS categories (Hole et al., 2011).

2) dynamic sustainability, i.e. ability to ensure a natural geographic distribution of biota and biocoenotic cover in changing environments.

The geographical location is a factor that largely determines inclination to a particular change. For example, with climate change-induced geographical range shifts, territories adjusting the range boundaries will be exposed to faster and more dramatic change. The proximity to the sea shore or to a large inland water body makes a PA prone to faster and more violent ecosystem change as a result of more active interaction between sea and land air masses, sea level change, coast erosion, etc. The proximity to areas of extreme climate (i.e. extremely high or low air temperatures, extreme aridity or precipitation, extraordinary rainfalls and hurricanes) makes a PA's territory potentially vulnerable. In extreme climates, ecosystems are always much more sensitive, and so a change that would be immaterial for a more stable climate may completely reshape, or even destroy, them (Stishov, 2012).

How much a territory will be affected by climate change-induced landscape and ecosystem reshape (climate change-induced geographical range shifts) depends on its size. Landscape diversity determines if more or fewer ecosystems will be unimpaired, or just slightly impaired, by climate change; it also contributes to sustaining populations and communities when climate change is un- favourable for them in various refugia (extrazonal habitats, etc.) (Stishov, 2012).

Of all landscapes, those related to permafrost and glacier ablation zone are the most sensitive to climate change. They quickly respond to increasing temperatures by restructuring the lithogenic base, which sometimes results in an irreversible change. Also very sensitive are coastal landscapes, which may be substantially impaired by the increasing sea level or by coastal erosion (Stishov, 2012).

Extrazonal and relic diversity of biota is a favourable factor improving landscape resilience. With tangible climate change effects, extrazonal and relic elements may become a natural basis, on which new biotic complexes can develop to fit the new climate conditions. Connections between PAs and other undisturbed, or low-disturbed, territories allow for more or less natural and free migration of not just some species, but of the whole flora and fauna complexes (Stishov, 2012).

Our resilience assessment research allows it to reveal the indications of a territory's climate change vulnerability. A more accurate estimation of future climate change impacts requires a more serious and detailed research directly based on meteorological and climate information, maps, and remote sensing data.

Research institutes of Roshydromet and the RF Academy of Science have analysed the available methods and developed a new one to assess 
climate change implications for physical and biological systems (Semenov et al., 2012). The average annual temperature and precipitation trends are important indicators, yet not nearly as informative for practical purposes as the parameters that can seriously affect biota/landscapes/economy. These parameters primarily include a variety of extremes, but also:

- the number of days with precipitation above 30 $\mathrm{mm}$ (i.e. frequency of extremely heavy precipitation);

- the largest five-day precipitation in a given month (this parameter describes the intensity of the heaviest precipitation series, including those resulting from strong front systems and cyclones);

- the number of days that meet the atmospheric drought criteria (diurnal precipitation less than $5 \mathrm{~mm}$ with a maximum air temperature above $25^{\circ} \mathrm{C}$ at middle and high latitudes or above $30^{\circ} \mathrm{C}$ at low latitudes);

- the number of days with $10 \%$ probability of minimum air temperatures (i.e. integral occurrence of the climate parameter is below or above certain thresholds) for two or more consequent days;

$-10 \%$ probability of minimum air temperatures;

$-90 \%$ probability of maximum air temperatures;

- the number of days with more than $7^{\circ} \mathrm{C}$ decrease in the average daily temperatures compared to the previous day (such situations correspond to the most intense cold fronts that often bring squalls, tornadoes, etc.);

- duration of the frost-free period over a year;

- duration of the vegetation period (the number of days in a calendar year with an average air temperature above $5^{\circ} \mathrm{C}$ for five or more consequent days) (Semenov, 2012).

Also important are:

- minimum air temperatures over a year;

- maximum air temperatures over a year;

- maximum wind gust speed, wind direction;

- snow thickness;

- frequency of air temperature crossing the $0^{\circ} \mathrm{C}$ threshold;

- the number of fine/cloudy days;

- the number of foggy days;

- the number of thunderstorm days.

The above list of key climate parameters is the largest possible. It may be cut depending on the specific features of a particular territory. It is important to estimate exactly the parameters that can substantially affect living organisms and the landscape structure.

Information that would be useful for a quick assessment of a territory's climate change vulner- ability can be found in regulations that specify climate parameters for the construction of buildings and facilities in Russia's regions, because a similar set of parameters is used in the construction sector (Building Climatology, 2012). For a primary assessment, one may want to look up information for the settlement nearest to a Protected Area (or weather station), if the climate conditions are similar (this makes sense for recently established PAs, which have not yet accumulated sufficient data series). The inventory specifies, that climate parameters for settlements that are not included in the tables and are located at the sea coast or by large inland water bodies, or in areas above 500 $\mathrm{m}$ in altitude, or more than $100 \mathrm{~km}$ away from the weather station, should be determined through inquiries to the Building Physics Research Institute (NIISF RAASN), Voeikov Main Geophysical Observatory (MGO), or Roshydromet's territorial divisions for hydrometeorology and environmental monitoring (Building Climatology, 2012). While using the inventory it is important to remember about the sensitivity of living organisms to favourable and unfavourable events, as well as the ability of animal species to migrate and of plant species to invade new territories. The seasonality factor plays an important role in the building climatology, and so plenty of data in inventories are split, which is also useful to assess the situation in a Protected Area. The following parameters are important all year round:

- average monthly and annual air temperature, ${ }^{\circ} \mathrm{C}$;

- mean and maximum ambient air temperature diurnal range.

For the cold season the following parameters are used:

- air temperature of the coldest day, ${ }^{\circ} \mathrm{C}$;

- air temperature of the coldest 5-day period, ${ }^{\circ} \mathrm{C}$;

- mean ambient air temperature, ${ }^{\circ} \mathrm{C}$;

- absolute minimum ambient air temperature, ${ }^{\circ} \mathrm{C}$;

- average daily air temperature range of the coldest month, ${ }^{\circ} \mathrm{C}$;

- duration (number of days) and average air temperature $\left({ }^{\circ} \mathrm{C}\right)$ of periods with average daily air temperatures $\leq 0^{\circ} \mathrm{C}, \leq 8^{\circ} \mathrm{C}, \leq 10^{\circ} \mathrm{C}$;

- average monthly relative air humidity of the coldest month, \%;

- average monthly relative air humidity of the coldest month at 15:00, \%;

- precipitation from November through March, mm;

- prevailing wind direction from December through February; 
- maximum speed of average wind speeds by directions in January, $\mathrm{m} / \mathrm{sec}$;

- average wind speed, $\mathrm{m} / \mathrm{sec}$, for a period of average daily air temperature $\leq 8^{\circ} \mathrm{C}$;

The following parameters are used for the warm season:

- average air temperature, ${ }^{\circ} \mathrm{C}$;

- average maximum air temperature of the warmest month, ${ }^{\circ} \mathrm{C}$;

- absolute maximum air temperature, ${ }^{\circ} \mathrm{C}$;

- average daily air temperature range of the warmest month, ${ }^{\circ} \mathrm{C}$;

- average monthly relative air humidity of the warmest month, \%;

- average monthly relative air humidity of the warmest month at 15:00, \%;

- precipitation from April through October, mm;

- daily precipitation maximum, $\mathrm{mm}$;

- prevailing wind direction from June through August;

- minimum speed of average wind speeds by directions in July, $\mathrm{m} / \mathrm{sec}$;

The above assessment methods are based on decades-long statistical data and help estimate trends by comparing the recent data against the baseline period.

A special challenge is to use projections to assess future climate change and its implications.

\section{Practical use of climate data}

What conclusions related to a territory's climate and implications for ecosystems can be drawn from the above data set?

First of all, trends and projected evolution of average temperatures and precipitation can be used to assess the shape of ecosystems and individual species: basic changes may be favourable for some of them, but immaterial or negative for others. So lists and maps can be developed to better focus on the conservation of vulnerable species and ecosystems.

Changes in the average annual, seasonal, and monthly temperatures normally well correlate with phenological phase shifts. However, for a concrete year, weather parameters and extreme events may cause deviations either way. For example, a cold winter and a warm spring may offset each other resulting in a year with no change in mean annual temperature, yet with an earlier beginning of the vegetation period.

Extreme weather events are not only intrinsically hazardous, but they ought to be considered in combination with their impacts.
Heat waves and droughts bring increased fire danger, and not in the forest zone alone. However, in $95 \%$ of all the cases a fire starts with an anthropogenic source. A dry thunderstorm or a drop of wood tar is a rare cause for the fire.

Abundant snowfalls may be a serious problem for ungulates and provoke avalanches in mountainous areas.

Damage from ice rain and snow crust depends on the thickness of the skare, and on whether or not it reaches down to the soil, and on how long it persists. Besides, it is important how frequent such events are. In Finland, some 30 years ago thaws and skare occurred just once in a winter, and not every year, whereas nowadays they happen 3 or 4 times every winter posing serious problems for reindeer breeding (Roturier et al., 2017).

Heavy rainfall may bring floods and mudflows, and the damage induced thereby depends not only on the precipitation amount, but also on the types of landscape and on how badly disturbed they are. Deforestation, disturbed vegetation cover, and steep slopes can exacerbate the adverse effects many times over.

With heavy rainfall and floods, it is also important to assess the perspectives for coast erosion and changes in riverbeds, potential development of jams and the impacts they may have, as well as karst formation processes.

Fog and poor visibility can make work in PAs difficult and temporarily cancel tourist excursions; but what is worse, they can affect the yield of insectpollinated plants and, therefore, animal feedstock.

Hurricane-induced damage depends on the wind speed, but also on the season of the year, air temperature, precipitation during and before the hurricane, wind direction, vegetation. On the sea shore, the wave height also plays a role of importance. For example, strong wind in Khakassia in 2015 coincided with a severe drought and brought a substantial damage, because in some localities it was impossible to put out the spreading fire, and propagation speed increased with wind (Report on climate features, 2016). Dust- and snowstorms are mostly seasonal events. For their specificity, spruce forests are much more vulnerable to hurricanes than pine or mixed forests. Where blocks of ice are cast ashore by a sea storm, damage to the coastal infrastructure is greater. Coast erosion depends on the mechanical performance of the coast rock and the freeze-thaw process. Mountain slopes may perform a protection function (the wind shadow effect) or enhance wind speed increase (wind- 
channel effect in valleys, the Novaya Zemlya and Novorossiysk bora, foehn wind).

\section{Climate change vulnerability assessment case study for a Protected Area}

The WWF has accomplished Russia's first comprehensive detailed research about the climate change impact on a Protected Area - Vaigach Island (Aleynikov et al., 2014).

The first stage of the Vaigach Island research included the development of a detailed climate inventory and an assessment of climate change trends over the recent decades. This was followed by a CMIP5-modelling of climate change for the next 30 years using a recognised international methodology.

CMIP5 (Coupled Model Intercomparison Project Phase 5) is a set of co-ordinated experimental climate models of the fifth generation under the World Climate Research Program. The CMIP5 project is using a standard set of model experiments aiming to: 1) assess the models' practicability for modelling the recent past, 2) present climate change projections on two time horizons: short-term (approximately to 2035) and long-term (2100 and beyond), and identify factors that determine projection error, including related to the cloudiness and the carbon cycle (Taylor et al., 2012; CMIP5, 2017).

This timescale was selected, on the one hand, to correlate with the long-term strategic planning period, and on the other, to avoid the ambiguity of various climate scenarios. Data were verified through a re-analysis, i.e. a test of how well the model correlates with observations after 1960 . The re-analysis was accomplished in the Climate change laboratory of the Institute of Global Climate and Ecology of Roshydromet and the Russian Academy of Science.

CMIP5-modelling is normally practiced for large regions. A forecasting climate change for a territory of around $3400 \mathrm{~km}^{2}$ is a difficult challenge and was performed for the first time ever. The results are inspiring. Although forecasting for a mountainous area will be more difficult, MGO is currently developing a $25 \mathrm{~km}$ resolution climate projection map for the entire country, which can be used for reference.

While the difference between detailed meteorological statistics and low-resolution projections may be discouraging, it is understandable and corresponds to the current level of scientific information. It is important to compare current trends against projections, so as to understand the processes which can help estimate potential impacts of climate change on PAs (Heller \& Zavaleta, 2009). In reality, it is only possible to forecast an average annual and average seasonal temperature change, as well as changes in the minimum and maximum temperature, with a confidence interval. It is also possible to identify precipitation trends (average), mean and maximum potential wind speed. It seems like it is not too much. However, projections of any other parameters would not be reliable.

Because climate data have low spatial resolution, the project's goal was to collect as detailed ecosystem-related information as possible. This allowed it to develop a set of 1:50,000 maps, including a geomorphological map, a map of freeze-thaw process, a hydrological map, a vegetation map, and a landscape map (Fig. 2). In addition, the following 1:250,000 maps were developed: geological, soil, territory use by local people, and anthropogenic disturbance. Thematic interpretation of high resolution color photos and field studies were used for developing the maps, and so very detailed information on the current shape of basic ecosystem elements was obtained.

«A map of the territory use by various environmental groups of birds and mammals» was developed using thematic maps, field studies, and relevant literature (Fig. 3). In fact, the most characteristic animal species were identified for each unit of the vegetation map (with an account of the other thematic maps), as well as their preferred uses of the territory (summer/winter pasture, nesting/feeding/rookery place, etc.).

Then each of the experts compared the obtained data against climate change projections and came up with conclusions regarding a potential change for his object. Analysis of landscape evolution and ecosystem suitability for various animal groups integrated the results obtained by other experts as well.

Climate projection overlapping data on landscapes and their potential dynamics allowed for the development of a 1:2,000,000 map of impacts of climate change-induced events on ecosystems (Fig. 4). This map clearly displays, which parts of the territory are particularly vulnerable to specific climate factors. Of note, it turned out that the major adverse effects include hurricanes, storm-induced coast erosion, and formation of a hard ice crust, rather than permafrost thawing in response to the increasing average annual air temperature, albeit to a certain degree the freeze-thaw process manifests across the whole island, inter alia, through expected change in hydrological facilities (Aleynikov et al., 2014). 
a)

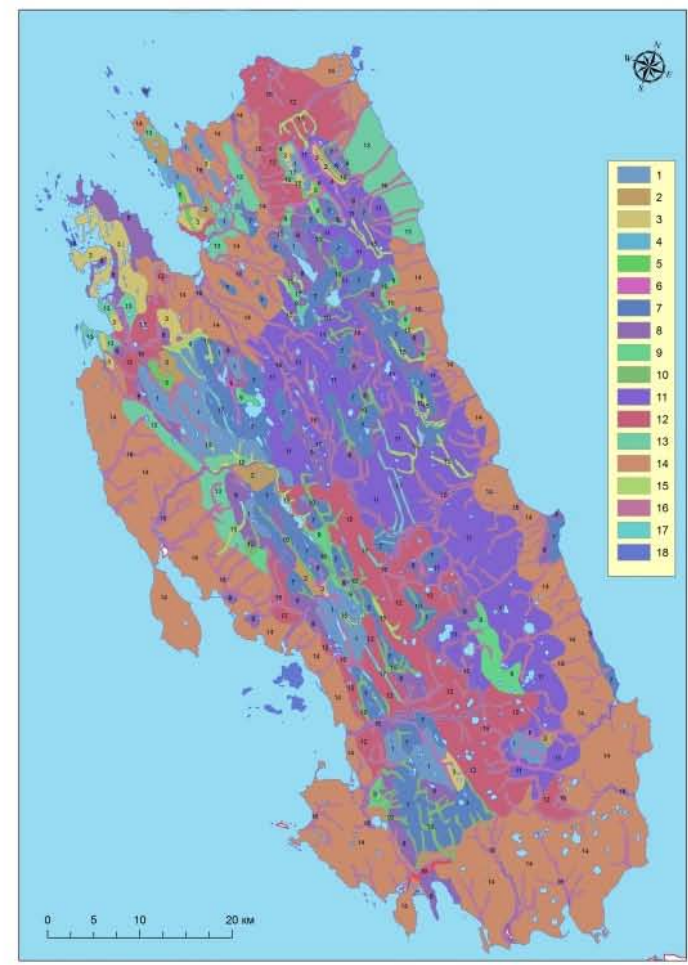

b)

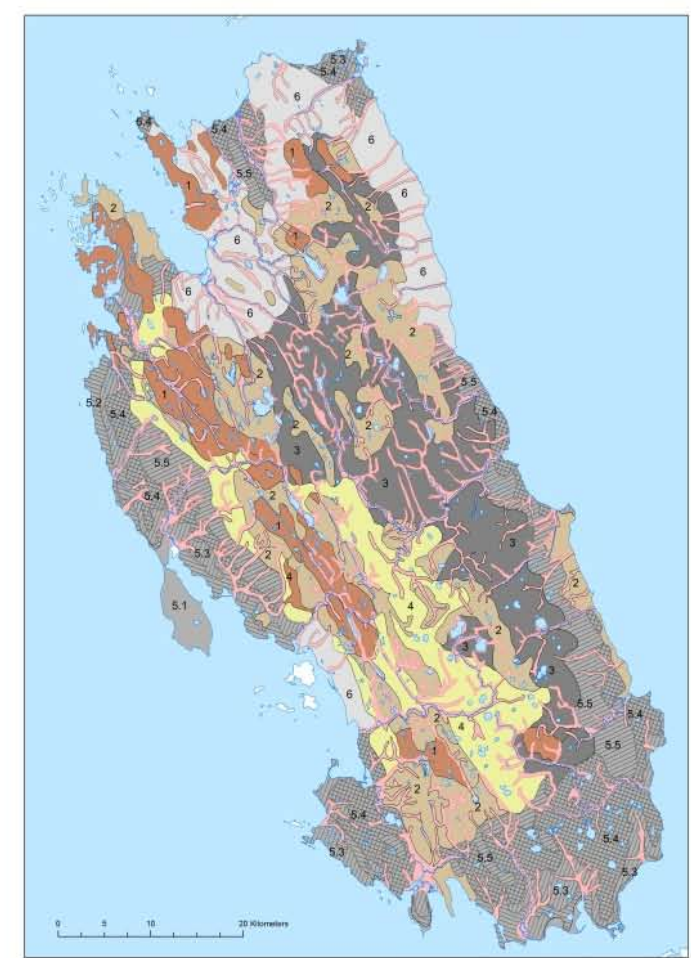

$\otimes$

c)

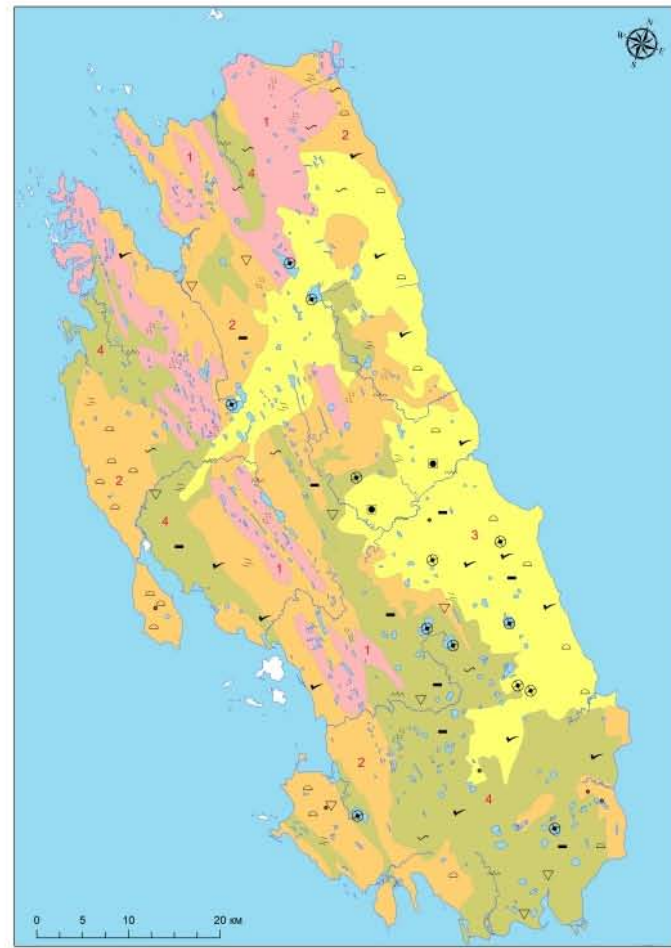

d)

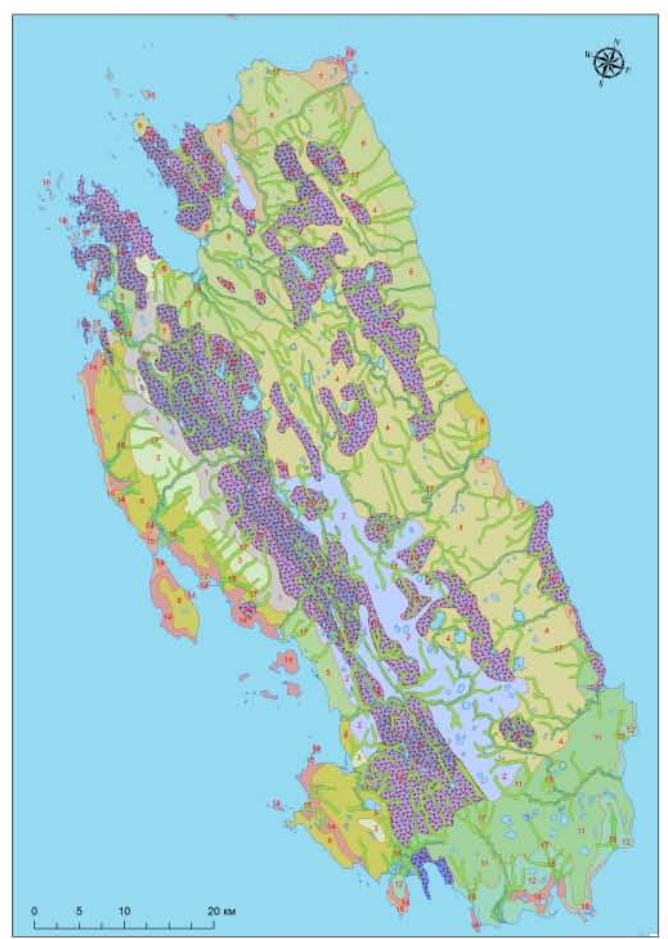

Fig. 2. Examples of thematic maps to assess a territory's vulnerability to a climate change: a) landscape, b) geomorphological, c) cryogenic processes, d) vegetation (Aleynikov et al., 2014).

The research was accomplished with the involvement of more than 30 experts from Moscow State University and institutes of the Russian Academy of Science and required complicated climate modelling, two years of work and field studies.

\section{The use of nature records}

Nature reserves and national parks have accumulated data series from nature records. Where these records have been kept for more than 30 years and accumulated sufficient information regarding weather, 
vegetation change, new animal species, seasonality, migration, and weather calendars, a primary assessment of climate change manifestation and trends for the PA can be made. Nature records management methodology suggested by Filonov \& Nukhimovskaya (1990) includes nearly all observation parameters. Typically, resource restrictions make it difficult for a relatively small team of a scientific division to follow all of the recommendations. Meteorological information is not always available in its entirety either. For example, in a perfect world, meteorological observations would be made in each altitudinal vegetation belt (Filonov \& Nukhimovskaya, 1990). Very good idea, hardly feasible in reality though.

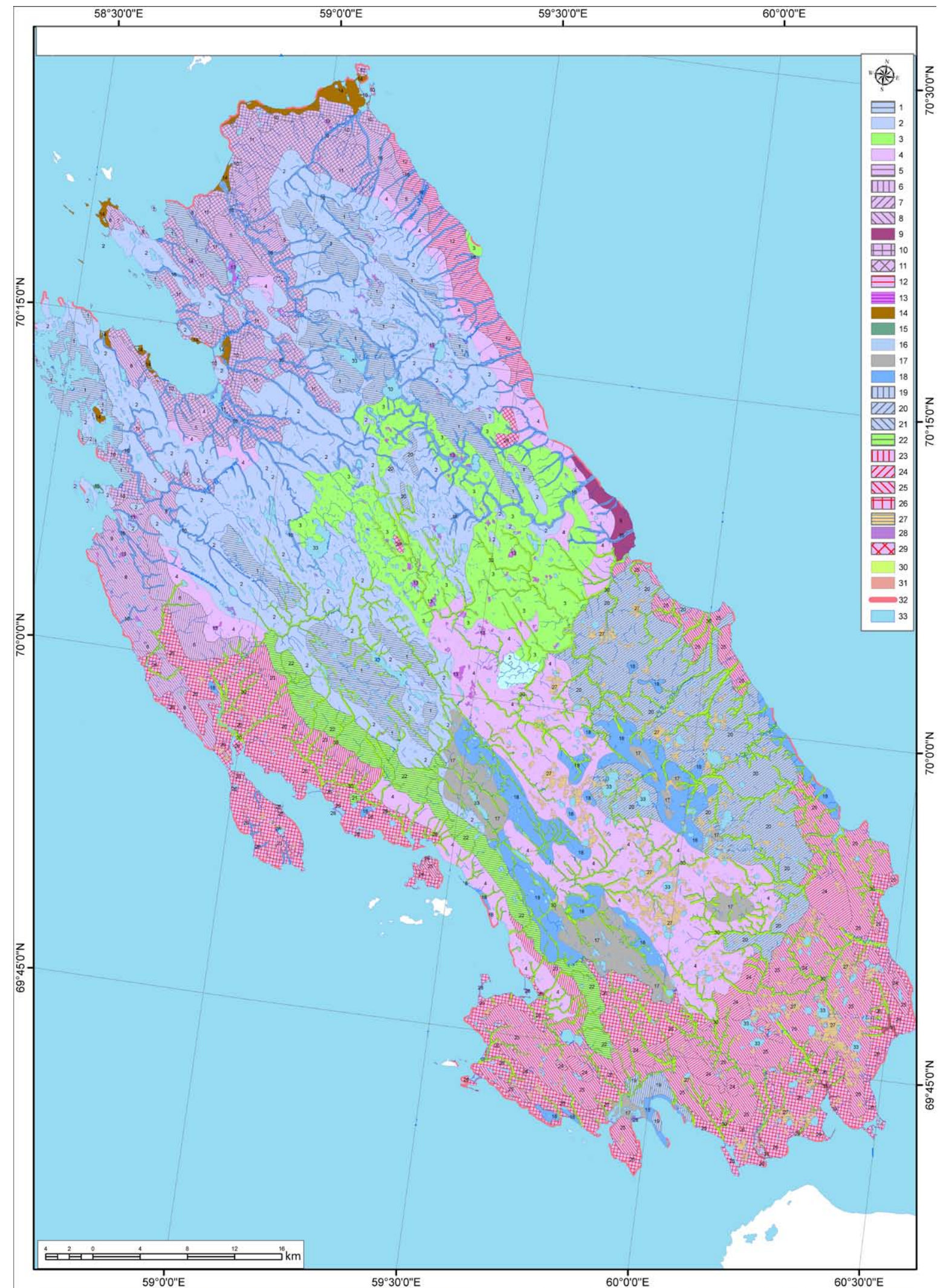

Fig. 3. Map of territory use by various environmental groups of birds and mammals (Aleynikov et al., 2014). 


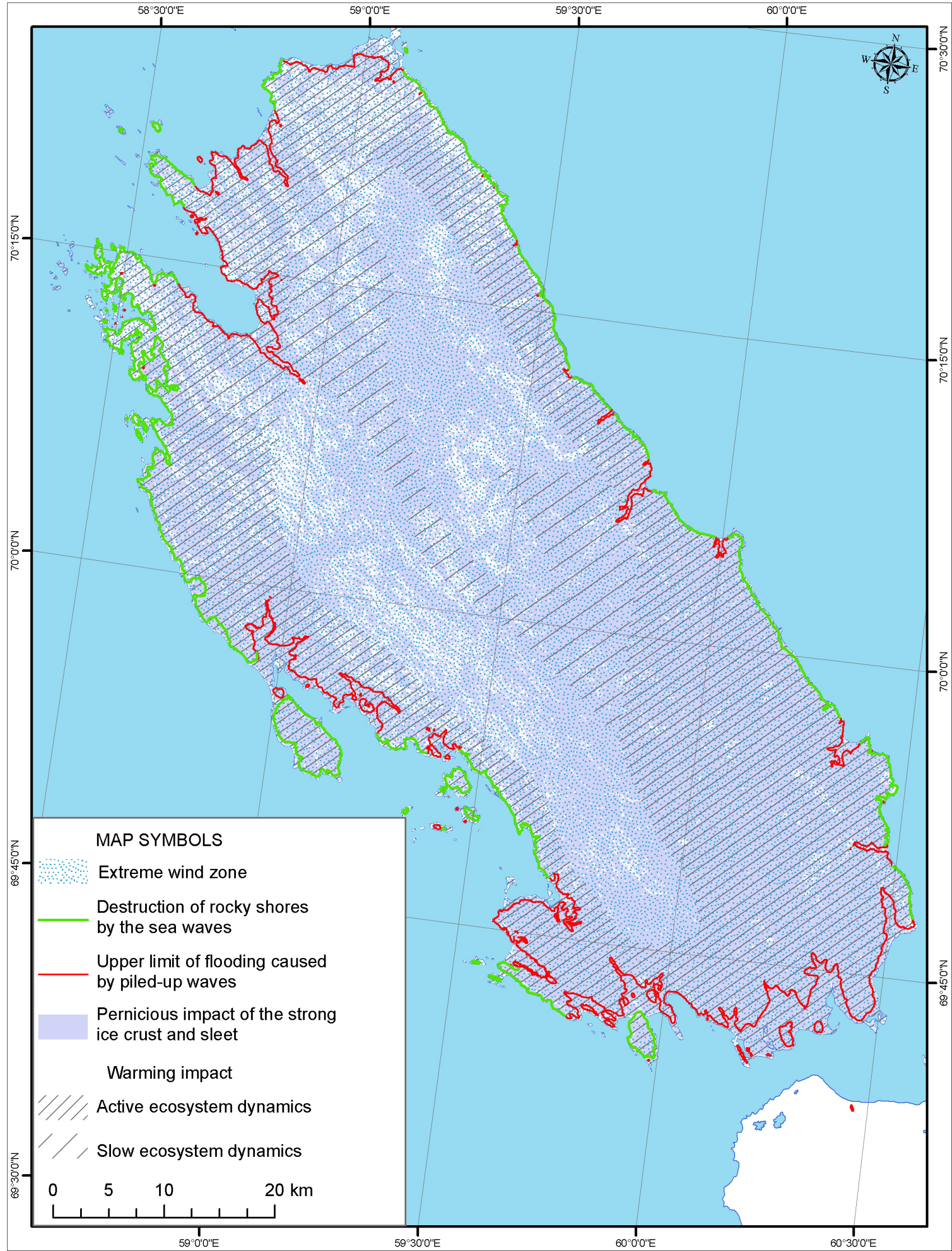

Fig. 4. Impacts of climate change-induced events on ecosystems (Aleynikov et al., 2014).

Nevertheless, analysis and assessment of decades-long data on weather change, extreme weather events and related change in ecosystems and species distribution is an important challenge for conservation science. By comparing data collected in PAs against climate research findings and projections, one can identify trends for the next two or three decades. It would be practical 
to map current climate vulnerabilities of PAs with zones determined by the scale of effects produced by adverse factors. Such maps could help develop comprehensive action plans including, inter alia, advanced fire protection system, guaranteed safety of personnel and tourists in zones with extreme flood/mudflow/avalanche hazards, artificial watering places and/or supplementary feeding for ungulates in winter, etc.

However, in most PAs, two or more factors have already manifested urging immediate action, even before the comprehensive climate assessment of the territory is accomplished. Where this is the case, climate information can help appropriately substantiate investment demand and develop future scenarios. Statistically, an investment demand for climate change adaptation is $20-30$ or more times lower, than climate change damage estimate where no adaptation measures are taken (Semenov et al., 2012).

\section{Conclusions}

At the current climate science development stage, information on actual and projected climate change is sufficient to allow for the development of adaptation plans for PAs.

Case studies, data sources, methodological approaches are developed and can be used to assess climate change vulnerability of PAs. They have proved effective on the regional level, yet application on the local level is a much more difficult challenge that requires detailed information about the territory, particularly in the mountains.

Nature records are an important source of information. Today, conservation science's main goal is to assess them in connection with climate change, supplement with the necessary climate data, and develop required adaptation measures.

\section{References}

Aleynikov A.A., Aleynikova A.M., Bocharnikov M.V., Glazov P.M., Golovlev P.P., Gruza G.V., Dobrolyubova K.O., Evina A.I., Zhbanova P.I., Zamolodchikov et al. 2014. Vaigach Island: nature, climate and people / O.N. Lipka (Ed.). Moscow: WWF. 542 p. [In Russian]

Assessment Report on climate change and implications in the territory of the Russian Federation. Vol. 1. Climate change. Moscow: Roshydromet, 2008. 230 p. [In Russian]

Assessment Report on climate change and implications in the territory of the Russian Federation. Vol. 2. Implications of climate change. Moscow: Roshydromet, 2008. 291 p. [In Russian]

Building climatology. Updated standard SNiP 23-01-99*. Code of rules SP 131.13330.2012. Moscow: Ministry of regional development of the Russian Federation, 2012. [In Russian]
CMIP5 - Coupled Model Intercomparison Project. 2017. Retrieved from: http://cmip-pcmdi.llnl.gov/cmip5/

Ervin J. 2003. WWF: Rapid Assessment and Prioritization of Protected Area Management (RAPPAM) Methodology. Gland, Switzerland. 52 p.

Filonov K.P., Nukhimovskaya Yu.D. 1990. Nature records in the USSR natural reserves. Teaching guide. Moscow: Nauka. 143 p. [In Russian].

Hannah L. 2008. Protected Areas and Climate Change. Annals of the New York Academy of Sciences 1134: 201212. DOI: 10.1196/annals.1439.009.

Hannah L., Midgley G., Hughes G., Bomhard B. 2005. The View from the Cape: Extinction Risk, Protected Areas, and Climate Change. BioScience 55(3): 231-242. DOI: 10.1641/0006-3568(2005)055[0231:TVFTCE]2.0.CO;2

Heller N.E., Zavaleta E.S. 2009. Biodiversity management in the face of climate change: A review of 22 years of recommendations. Biological Conservation 142: 14-32. DOI: 10.1016/j.biocon.2008.10.006.

Hole D.G., Huntley B., Arinaitwe J., Butchart S.H.M., Collingham Y.C., Fishpool L.D.C., Pain D.J., Willis S.G. 2011. Toward a Management Framework for Networks of Protected Areas in the Face of Climate Change. Conservation Biology 25(2): 305-315. DOI: 10.1111/j.1523-1739.2010.01633.x.

III-VI National Communication of Kazakhstan Republic to the UN Framework Convention on Climate Change (UNFCCC). Astana, 2013. 265 p. Available at: https:// unfccc.int/files/national_reports/annex i natcom_application/pdf/kaz nc3,4,5,6 eng.pdf

IPCC. 2013. Climate Change 2013: The Physical Science Basis. Contribution of Working Group I to the Fifth Assessment Report of the Intergovernmental Panel on Climate Change / T.F. Stocker, D. Qin, G.-K. Plattner, M. Tignor, S.K. Allen, J. Boschung, A. Nauels, Y. Xia, V. Bex, P.M. Midgley (Eds.). Cambridge, United Kingdom and New York, USA: Cambridge University Press. 1535 p.

IPCC. 2014: Climate Change 2014: Impacts, Adaptation, and Vulnerability. Part A: Global and Sectoral Aspects. Contribution of Working Group II to the Fifth Assessment Report of the Intergovernmental Panel on Climate Change / C.B. Field, V.R. Barros, D.J. Dokken, K.J. Mach, M.D. Mastrandrea, T.E. Bilir, M. Chatterjee, K.L. Ebi, Y.O. Estrada, R.C. Genova, B. Girma, E.S. Kissel, A.N. Levy, S. MacCracken, P.R. Mastrandrea, L.L. White (Eds.). Cambridge, United Kingdom and New York, USA: Cambridge University Press. 1132 p.

Klausmeyer K.R., Shaw M.R. 2009. Climate Change, Habitat Loss, Protected Areas and the Climate Adaptation Potential of Species in Mediterranean Ecosystems Worldwide. PLoS ONE 4(7): e6392. DOI: 10.1371/ journal.pone.0006392

Kokorin A.O. (Ed.). 2011. Climate change and implications for ecosystems, population and economy of the Russian part of the Altai-Sayan ecoregion: assessment report. Moscow: WWF-Russia. 168 p. [In Russian]

Kokorin A.O., Lipka O.N., Sulyandziga R.V. 2015. Climate Change. Glossary of terms used by UNFCCC. Moscow: WWF-Russia. 92 p. [In Russian] 
Kokorin A.O., Smirnova E.V., Zamolodchikov D.G. 2013a. Climate Change. Textbook for teachers in upper secondary school. Issue 1. Regions of the North European part of Russia and West Siberia. Moscow: WWF. 220 p. [In Russian]

Kokorin A.O., Smirnova E.V., Zamolodchikov D.G. 2013b. Climate Change. Textbook for teachers in upper secondary school. Issue 2. Regions of the Russian Far East. Moscow: WWF. 234 p. [In Russian]

Loarie S.R., Duffy P.B., Hamilton H., Asner G.P., Field C.B., Ackerly D.D. 2009. The velocity of climate change. $\mathrm{Na}$ ture 462: 1052-1055. DOI: 10.1038/nature08649

Mawdsley J.R., O’Malley R., Ojima D.S. 2009. A review of climate-change adaptation strategies for wildlife management and biodiversity conservation. Conservation Biology 23(5): 1080-1089. DOI: 10.1111/j.1523-1739.2009.01264.x

McLeod E., Salm R., Green A., Almany J. 2009. Designing marine protected area networks to address the impacts of climate change. Frontiers in Ecology and the Environment 7: 362-370. DOI: 10.1890/070211.

Olson D., O’Connell M., Fang Y.-Ch., Burger J., Rayburn R. 2009. Managing for Climate Change within Protected Area Landscapes. Natural Areas Journal 29(4): 394 399. DOI: $10.3375 / 043.029 .0406$

Post E., Forchhammer M.C., Syndonia M.B.-H., Callaghan T.V., Christensen T.R., Elberling B., Fox A.D., Gilg O., Hik D.S., Høye T.T., Ims R.A., Jeppesen E., Klein D.R., Madsen J., McGuire A.D., Rysgaard S., Schindler D.E., Stirling I., Tamstorf M.P., Tyler N.J.C., van der Wal
R., Welker J., Wookey P.A., Schmidt N.M., Aastrup P. 2009. Ecological Dynamics Across the Arctic Associated with Recent Climate Change. Science 325(5946): 1355-1358. DOI: 10.1126/science.1173113.

Report on climate features in the territory of the Russian Federation - 2015. Moscow, 2016. 68 p. [In Russian]

Report on climate features in the territory of the Russian Federation - 2016. Moscow, 2017. 70 p. [In Russian]

Roturier S., Nygård J., Nutti L.-E., Åstot M.-P., Roué M. 2017. Reindeer husbandry in the boreal forest: Sami ecological knowledge or the science of «working with nature». In: M. Roué, Z. Molnár (Eds.): Knowing our Lands and Resources Indigenous and Local Knowledge of Biodiversity and Ecosystem Services in Europe and Central Asia. Paris: UNESCO. 90-108.

Second assessment report on climate change and its implications in the territory of the Russian Federation. Moscow: Roshydromet, 2014. 1008 p. [In Russian]

Semenov S.M. (Ed.). 2012. Methods to evaluate implications of climate change for physical and biological systems / S.M. Semenov (Ed.). Moscow: Roshydromet. 511 p. [In Russian]

Stishov M.S. 2012. Methodology to evaluate the nature protection efficiency of protected areas and their regional systems. M.: WWF-Russia. 284 p. [In Russian]

Taylor K.E., Stouffer R.J., Meehl G.A. 2012: An overview of CMIP5 and the experiment design. Bulletin of the American Meteorological Society 93: 485-498. DOI: 10.1175/bams-d-11-00094.1.

WWF Adapt. World Wildlife Fund, 2017. Retrieved from: http://wwfadapt.org/

\title{
МЕТОДИЧЕСКИЕ ПОДХОДЫ ДЛЯ ОЦЕНКИ УЯЗВИМОСТИ ОСОБО ОХРАНЯЕМЫХ ПРИРОДНЫХ ТЕРРИТОРИЙ К ИЗМЕНЕНИЯМ КЛИМАТА
}

\author{
О. Н. Липка \\ Всемирный фонд дикой природы (WWF России), Россия \\ e-mail:olipka@wwf.ru
}

В связи с изменениями климата на территории России задача сохранения видов и экосистем на особо охраняемых природных территориях становится более сложной. Возникла необходимость в принятии дополнительных адаптационных мер. Для их разработки необходимо, прежде всего, оценить степень уязвимости территории: что и в какой степени подвержено неблагоприятным климатическим воздействиям? Проведенный анализ позволит разработать порядок действий, соответствующих современной ситуации нестабильного экстремального климата и прогнозам ведущих научных институтов Росгидромета и Российской Академии Наук. В настоящий момент уже разработаны и успешно апробированы для некоторых природных зон методики. Перед заповедной наукой встает новая задача: соединить накопленные данные с климатическими прогнозами и определить перспективы развития ситуаций для конкретных территорий.

Ключевые слова: изменение климата, особо охраняемые природные территории, уязвимость к изменениям климата 